\title{
KRITIK TERHADAP KITAB SHAHIH AL-BUKHARI DAN SHAHIH MUSLIM
}

Oleh: Marzuki

(FISE - UNY)

\begin{abstract}
Abstrak
Para ulama telah sepakat tentang keautentikan hadis-hadis yang termuat dalam kitab Shahih al-Bukhari dan Shahih Muslim. Namun sekarang, sebagian ulama sudah mulai melakukan kritik dan penelitian ulang terhadap hadis-hadis yang ada dalam kedua kitab Shahih tersebut.

Nama lengkap al-Bukhari adalah Abu Abdillah Muhammad bin Isma'il bin Ibrahim bin al-Mughirah bin Bardizbah al-Ja'fi alBukhari. hafalan yang sangat kuat. Ia menghafal 100.000 hadis shahih dan 200.000 hadis yang tidak shahih, di samping juga menguasai berbagai ilmu, terutama yang terkait dengan hadis. Di antara buku-buku yang ditulis al-Bukhari, yang paling terkenal adalah al-Jami' al-Shahih yang terkenal juga dengan nama Shahih al-Bukhari. Sedang nama lengkap Muslim adalah Abu al-Husain Muslim bin al-Hajjaj al-Qusyairi al-Naisaburi. Imam Muslim juga dikenal sebagai ahli hadis yang memiliki tingkat hafalan yang tinggi sebagaimana al-Bukhari. Dari karya-karya Muslim, yang paling terkenal adalah kitab Jami' al-Shahih atau dikenal dengan Shahih Muslim.

Dua kitab hadis shahih yang ditulis al-Bukhari dan Muslim (alShahihain) merupakan dua kitab hadis yang paling populer di kalangan umat Islam hingga sekarang dan diakui sebagai kitab yang paling autentik setelah al-Quran. Meskipun dua kitab hadis shahih tersebut memiliki kedudukan yang sangat tinggi dan hampir semua ulama hadis sepakat akan keautentikan hadis-hadis dalam kedua kitab tersebut, ternyata kedua kitab hadis ini tidak luput dari adanya kritik. Kritik terhadap kedua kitab ini tidak hanya dilontarkan oleh para orientalis, tetapi juga dari para ulama hadis sendiri. Kritik ini terkadang diarahkan kepada penulisnya, yakni al-Bukhari dan Muslim, dan terkadang juga diarahkan kepada metode yang digunakan oleh keduanya dalam penyusunan kedua kitab tersebut. Kritik dan sorotan yang diarahkan kepada dua kitab al-Shahihain tersebut hingga kini masih muncul, terutama dalam hal matan atau isi hadisnya.
\end{abstract}




\section{Pendahuluan}

Hampir semua ulama hadis sepakat bahwa kitab hadis yang memuat hadis-hadis yang paling autentik adalah dua kitab hadis yang ditulis oleh Imam al-Bukhari dan Imam Muslim. Dua kitab hadis itu dikenal dengan nama Shahih al-Bukhari dan Shahih Muslim. Kitabkitab hadis yang berada pada tingkatan di bawah dua kitab itu adalah kitab-kitab Sunan, terutama yang ditulis oleh Imam Abu Daud, Imam al-Nasa'i, Imam al-Tirmidzi, dan Imam Ibnu Majah. Dua kitab Shahih yang ditulis al-Bukhari dan Muslim hanya memuat hadis-hadis yang shahih saja, sedang hadis-hadis yang dimuat dalam empat kitab Sunan itu tidak hanya hadis-hadis shahih, tetapi juga hadis-hadis yang hasan. Setelah kitab shahih dan sunan ini ada kitab musnad yang ditulis oleh Imam Ahmad Ibnu Hanbal yang memuat hadits shahih dan hasan serta hadis dla'if.

Al-Nawawi dalam salah satu kitabnya dengan tegas mengatakan bahwa para ulama telah sepakat tentang keautentikan hadis-hadis yang termuat dalam kitab Shahih al-Bukhari dan Shahih Muslim (alNawawi, 1402 H, I: 14). Namun pada masa-masa sesudahnya, pernyataan al-Nawawi ini sudah tidak lagi dipegangi oleh semua ulama hadis. Sebagian ulama sudah mulai melakukan kritik dan penelitian ulang terhadap hadis-hadis yang ada dalam kedua kitab Shahih tersebut.

Pada akhir abad ke-19 Masehi umat Islam dikejutkan dengan penelitian seorang orientalis terkenal kelahiran Hungaria, Ignaz Goldziher, tentang hadis Nabi. Dalam penelitiannya yang berjudul Mohammedanische Studien, Goldziher membantah otentisitas hadishadis yang selama ini dipegangi oleh umat Islam. Menurutnya hadis Nabi tidak lebih dari produk perkembangan keadaan sosial politik Islam pada waktu itu. Apa yang dilakukan oleh Goldziher juga diikuti oleh orientalis lainnya, seperti Joseph Schacht. Dalam salah satu karyanya The Origins of Muhammadan Jurisprudence (1950), Schacht juga meragukan otentisitas hadis-hadis Nabi, khususnya hadis-hadis hukum (fikih) (Ali Mustafa Yaqub, 1996: 8-9).

Dari kajian kritis para orientalis terhadap hadis-hadis Nabi seperti yang dilakukan oleh Goldziher dan Schacht, para ulama hadis tertantang pula untuk melakukan penelitian atau kritik terhadap hadishadis yang selama ini dianggap tidak bermasalah. Salah satu ulama yang melakukan penelitian kritis terhadap hadis-hadis Nabi adalah Prof. Dr. Muhammad Musthafa A'zhami, guru besar Ilmu Hadis 
Universitas King Saud Riyadh Saudi Arabia. Hasil penelitiannya tentang hadis-hadis Nabi pada tahun 1967 tersebut kemudian dibukukan dengan judul Sudies in Early Hadith Literature (1968). Salah satu temuan A'zhami adalah bahwa hadis Nabi sudah ditulis pada waktu Nabi Muhammad Saw. masih hidup, dan tuduhan Goldziher dan Schacht tidak lebih hanya sekedar isapan jempol belaka (Ali Mustafa Yaqub, 1996: 9). Dengan kata lain apa yang dituduhkan oleh dua orientalis terkemuka itu tidak terbukti.

Permasalahan seperti di atas menjadi menarik mengingat selama ini mayoritas umat Islam merasa tidak memiliki masalah dengan hadis-hadis Nabi, apalagi terkait dengan hadis-hadis shahih yang dimuat dalam dua kitab hadis Shahih al-Bukhari dan Shahih Muslim. Atas dasar inilah, penulis akan mencoba mengkaji lebih dalam tentang kritik hadis, khususnya kritik terhadap kitab Shahih al-Bukhari dan Shahih Muslim yang memuat hadis-hadis Nabi yang shahih. Sebelum sampai pada permasalahan inti, akan diungkap terlebih dahulu biografi dari kedua imam hadis yang menyusun kitab Shahih tersebut.

\section{Biografi al-Bukhari dan Muslim}

\section{Al-Bukhari}

Nama lengkapnya adalah Abu Abdillah Muhammad bin Isma'il bin Ibrahim bin al-Mughirah bin Bardizbah al-Ja'fi al-Bukhari. Beliau dilahirkan pada hari Jum'at tanggal 13 Syawwal $194 \mathrm{H}$ di kota Bukhara. Ayahnya, Isma'il, adalah seorang ulama besar yang banyak meriwayatkan hadis dari Hammad bin Zaid dan Imam Malik. Ayah alBukhari tidak bisa menemaninya dalam waktu yang lama, sebab dia sudah wafat ketika al-Bukhari masih kanak-kanak. Ayahnya mewariskan sejumlah buku dan semangat untuk mencari ilmu, terutama hadis. Selanjutnya al-Bukhari diasuh oleh ibunya dengan penuh kasih sayang dan dengan bimbingan untuk selalu mencintai ilmu.

Dalam usianya yang masih relatif muda (11 tahun), al-Bukhari sudah mulai menuntut ilmu dan menghafal beberapa buku yang ditulis oleh para imam hadis di negerinya. Pada tahun $210 \mathrm{H}$ al-Bukhari bersama ibu dan saudaranya pergi ke Hijaz (Makkah) untuk melakukan ibadah haji. Selanjutnya al-Bukhari menetap di Madinah dan menulis kitab sejarah yang diberi nama al-Tarikh al-Kabir, di samping kuburan Nabi Muhammad Saw. Al-Bukhari memberikan tambahan pada kitab ini dua kali di akhir hidupnya (al-Khathib, 1989: $310)$. 
Al-Bukhari termasuk orang yang sangat cerdas dan memiliki hafalan yang sangat kuat. Ia menghafal 100.000 hadis shahih dan 200.000 hadis yang tidak shahih, di samping juga menguasai berbagai ilmu, terutama yang terkait dengan hadis. Dia pergi mencari hadis dari berbagai imam hadis di berbagai negeri, seperti Baghdad, Bashrah, Kufah, Makkah, Madinah, Syam, Hims, 'Asqalan, dan Mesir. Berkat kesabaran, kecerdasan, dan cintanya terhadap ilmu, al-Bukhari mencapai derajat tertinggi dalam hadis pada zamannya. Dia mendapat gelar Imam al-Mu'minin fi al-Hadis atau Amir al-Mu'minin fi alHadis (al-Khathib, 1989: 310).

Di akhir hayatnya, al-Bukhari kemudian pulang ke kampung halamannya, Bukhara. Beliau kemudian wafat di desa Khartank, dekat Samarkand, pada tanggal 30 Ramadlan (malam 'Idul Fitri) tahun 256 $\mathrm{H}$. Beliau wafat dengan meninggalkan mutiara Islam yang tiada taranya. Karya-karyanya kemudian menjadi pegangan bagi hampir semua ulama hadis setelahnya dalam melakukan kajian terhadap hadis.

Dari pengembaraannya di berbagai negeri, al-Bukhari bertemu dengan sekian banyak guru hadis. Ia menyatakan bahwa hadis-hadis yang ditulisnya diterima dari 1.080 guru hadis. Di antara gurunya yang terkenal adalah 'Ali bin al-Madini, Ahmad bin Hanbal, Yahya bin Ma'in, Muhammad bin Yusuf al-Faryabi, Makki bin Ibrahim alBulkhi, Muhammad bin Yusuf al-Baikandi, dan Ibnu Rahawaih. Guru-guru hadis yang diriwayatkan dalam kitab Shahihnya sebanyak 289 orang (Abu Syahbah, 1969: 49).

Adapun murid-muridnya diperkirakan tidak kurang dari 90.000 orang. Di antara mereka yang paling terkenal adalah Muslim bin alHajjaj, al-Tirmidzi, al-Nasa'i, Ibnu Khuzaimah, Ibn Abi Daud, Muhammad bin Yusuf al-Firabri, Ibrahim bin Ma'qal al-Nasafi, Hammad bin Syakir al-Nasawi, dan Manshur bin Muhammad alBazdawi. Empat murid terakhir ini termasuk perawi shahih yang termasyhur dari al-bukhari (Abu Syahbah, 1969: 50).

Sebagai orang yang sangat mencintai ilmu, al-Bukhari mempelajari berbagai ilmu dan juga menulis beberapa buku. AlBukhari menulis lebih dari dua puluh buku dalam bidang hadis, ilmu hadis, rijalul hadis, dan ilmu-ilmu lainnya. Di antara buku yang ditulisnya itu adalah al-Jami' al-Shahih, al-Adab al-Mufrad, al-Tarikh al-Shaghir, al-Tarikh al-Ausath, al-Tarikh al-Kabir, al-Tafsir alKabir, al-Musnad al-Kabir, dan Kitab al-ilal. Di antara buku-buku ini, yang paling terkenal adalah al-Jami' al-Shahih yang terkenal juga dengan nama Shahih al-Bukhari. 


\section{Muslim}

Nama lengkap Imam Muslim adalah Abu al-Husain Muslim bin al-Hajjaj al-Qusyairi al-Naisaburi. Dia juga digelari dengan hujjatul Islam. Ia dilahirkan di kota Naisabur pada tahun $204 \mathrm{H}$ (ada yang mengatakan tahun $206 \mathrm{H}$ ). Pada tahun $218 \mathrm{H}$ Muslim sudah berguru ke beberapa guru di negerinya, kemudian belajar ke luar dari negerinya. Ia pergi ke Baghdad beberapa kali serta bertemu dengan para imam hadis dan para penghafal hadis di tengah perjalanannya ke Hijaz, Iraq, Syam, Mesir, dan lain sebagainya (al-Khathib, 1989: 314).

Di antara guru-guru Imam Muslim yang terkenal adalah Imam Ahmad bin Hanbal, al-Bukhari, Sa'id bin Manshur, Abdullah bin Maslamah, Ishaq bin Rahawaih, Amr bin Sawwad, dan Muhammad bin Mahram. Sedangkan periwayat yang menerima riwayat dari Muslim di antaranya adalah al-Tirmidzi, Yahya bin Sha'id, Ibnu Khuzaimah, dan 'Abd al-Rahman bin Abi Hatim.

Imam Muslim juga dikenal sebagai ahli hadis yang memiliki tingkat hafalan yang tinggi. Ia menghafal ratusan ribu hadis. Di samping itu ia juga menulis beberapa karya yang dijadikan pegangan oleh para ulama sesudahnya. Di antara karya-karyanya yang terkenal adalah Jami' al-Shahih, Musnad al-Kabir, al-Jami' al-Kabir, Kitab al-'ilal wa Kitab Auham al-Muhadditsin, Kitab al-Tamyiz, dan Kitab al-Muhadlramin. Dari karya-karyanya ini, yang paling terkenal adalah kitab Jami' al-Shahih atau dikenal dengan Shahih Muslim.

Imam Muslim wafat pada tanggal 25 Rajab $261 \mathrm{H}$ di Nashr Ibad, salah satu desa di Naisabur. Imam Muslim mewariskan lebih dari dua puluh karya dalam bidang hadis dan ilmu hadis (al-Khathib, 1989: $315)$.

\section{Kajian terhadap Kitab Shahih al-Bukhari dan Shahih Muslim}

Dua kitab hadis shahih yang ditulis al-Bukhari dan Muslim (alShahihain) merupakan dua kitab hadis yang paling populer di kalangan umat Islam hingga sekarang. Dua kitab ini diakui sebagai kitab yang paling autentik setelah al-Quran. Namun di kalangan ulama terdapat perbedaan pendapat, mana yang lebih autentik di antara dua kitab itu. Jumhur ulama berpendapat bahwa Shahih al-Bukhari lebih autentik dibandingkan Shahih Muslim. Sedangkan sejumlah ahli hadis dari Maroko berpendapat bahwa Shahih Muslim lebih autentik dibandingkan Shahih al-Bukhari (Ali Mustafa Yaqub, 1996: 18).

Alasan yang dipegangi oleh jumhur ulama yang menyatakan bahwa Shahih al-Bukhari lebih autentik dibandingkan Shahih Muslim 
di antaranya adalah pertama, keunggulan pribadi al-Bukhari dari Muslim. Keluhuran pribadi al-Bukhari ini dituturkan oleh para tokoh hadis seperti al-Hakim Abu Ahmad al-Naisaburi, al-Daruquthni, Abu al-'Abbas al-Qurthubi, dan ulama lainnya. Kedua, metode pengambilan hadis yang dilakukan oleh al-Bukhari lebih unggul dibandingkan metode yang dilakukan Muslim. Salah satu metode yang ditempuh al-Bukhari untuk menunjukkan persambungan sanad adalah apabila murid dengan guru atau periwayat kedua dengan periwayat pertama benar-benar bertemu, meskipun hanya sekali. Sedang menurut Muslim persambungan sanad itu cukup dengan melihat kedua murid dan guru itu hidup dalam satu kurun waktu yang tempatnya tidak berjauhan, meskipun belum pernah bertemu.

Adapun ulama yang melihat keunggulan Sahih Muslim atas Shahih al-Bukhari, seperti para ulama Maroko, sebenarnya tidak mendasarkan pada nilai hadis yang dimuatnya, tetapi pada metode penyusunannya. Memang diakui oleh para ulama hadis bahwa metode penyusunan hadis dalam kitab Muslim lebih unggul dibandingkan dengan metode penyusunan hadis pada Shahih al-Bukhari.

Adapun spesifikasi dari dua kitab hadis shahih ini akan dijelaskan masing-masing sebagai berikut:

\section{Shahih al-Bukhari}

Kitab Shahih al-Bukhari merupakan kitab pertama yang disusun hanya memuat hadis-hadis shahih saja. Dalam kitab ini termuat 9.082 hadis yang sebagiannya berulang-ulang yang diseleksi al-Bukhari dari 600.000 buah hadis yang dikumpulkannya. Dengan kerja keras dan waktu yang cukup lama, sekitar 16 tahun, al-Bukhari dapat menyelesaikan penyusunan kitabnya yang dilakukan dengan dimulai shalat dua rekaat. Ini dilakukan agar kitabnya menjadi hujjah di antara dia dengan Allah Swt. (al-Khathib, 1989: 312).

Banyak para ulama hadis yang menaruh perhatian terhadap kitab Shahih al-Bukhari. Di antara mereka ada yang kemudian membuat Syarh dan Mukhtashar dari kitab tersebut. Di antara kitab Syarah yang ditulis dalam hal ini adalah al-Kawakib al-Dlarari fi Syarh al-Bukhari tulisan al-'Allamah Syamsuddin Muhammad bin Yusuf bin 'Ali al-Kirmani, Fath al-Bari bi Syarh Shahih al-Bukhari tulisan Ibnu Hajar al-'Asqallani, 'Umdat al-Qari' tulisan Badruddin Mahmud bin Ahmad al-'Aini, dan Irsyad al-Syari ila Shahih alBukhari tulisan Syihabuddin Ahmad bin Muhammad al-Khathib alMishri al-Syafi'i atau yang terkenal dengan nama al-Qasthallani. 
Adapun kitab Mukhtashar Shahih al-Bukhari di antaranya adalah Bahjat al-Nufus wa Ghayatuha bi Ma'rifat Ma Laha wa Ma 'Alaiha tulisan Abu Muhammad 'Abdullah bin Sa'd bin Abi Jamrah alAndalusi dan Mukhtashar tulisan Zainuddin Abi al-Abbas Ahmad bin 'Abdullathif al-Syarji al-Zubaidi (Abu Syahbah, 1969: 79).

\section{Shahih Muslim}

Imam Muslim menyusun kitabnya dalam waktu kurang lebih 15 tahun. Dia mengumpulkan hadis-hadis shahih di dalamnya sejumlah 4.000 buah yang diseleksi dari 300.000 hadis yang didengarnya. Dalam kitab itu, juga ada beberapa hadis yang berulang sebagaimana dalam kitab Shahih al-Bukhari. Jika tidak berulang, hadis yang ada dalam kitab ini berjumlah 3.030 buah. Imam Muslim menyatakan bahwa dalam kitabnya ini tidak ada hadis-hadis selain dari hadis shahih (al-Khathib, 1989: 315-316).

Dalam beberapa hal kitab Shahih Muslim dinilai lebih unggul dibandingkan dengan kitab Shahih al-Bukhari. Di antara keunggulannya adalah susunannya sangat baik, cara pengelompokan hadis berdasarkan matan yang sejenis, matan senantiasa utuh tanpa ada potongan yang berarti, memelihara penampilan hadis yang murni tanpa ada percampuran dengan fatwa shahabat dan tabi'in, dan proses penulisannya sangat teliti dengan bimbingan dari beberapa guru.

Sama seperti Shahih al-Bukhari, para ulama juga menulis Syarh dan Mukhtashar untuk kitab Shahih Muslim. Di antara kitab Syarh untuk Shahih Muslim adalah al-Mu'lim bi Fawaidi Kitab Muslim tulisan Abu 'Abdillah bin 'Ali al-Mazari, Ikmal al-Mu'lim fi Syarh Shahih Muslim tulisan Qadli 'Iyadl bin Musa al-Yahshabi al-Maliki, dan al-Minhaj fi Syarh Shahih Muslim tulisan al-Nawawi. Adapun kitab Mukhtashar Shahih Muslim di antaranya adalah Mukhtashar oleh al-Syeikh Abi 'Abdillah Syarf al-Din bin 'Abdillah, al-Mufham li Ma Asykala min Talkhishi Shahih Muslim oleh Imam al-Qurthubi, dan Mukhtashar oleh Imam al-Mundziri.

\section{Kedudukan Kitab Shahih al-Bukhari dan Shahih Muslim}

Kedua kitab Shahih yang ditulis oleh al-Bukhari dan Muslim (al-Shahihain) merupakan kitab hadis yang paling tinggi derajatnya di antara kitab-kitab hadis yang lain. Karena itu, dalam khazanah kitabkitab hadis, kedua kitab hadis ini memiliki kedudukan yang tertinggi. Tidaklah sah seorang pengkaji hadis jika tidak merujuk kepada kedua kitab Shahih ini. 
Ketinggian derajat kedua kitab ini di samping karena ditulis oleh dua ulama hadis yang paling terkemuka, juga memiliki pertimbangan lain. Keutamaan kedua kitab Shahih ini terletak pada ketelitian dan kecermatan kedua penulisnya dalam memilih periwayat sebagai penyampai hadis. Hadis-hadis yang dimasukkan ke dalam kedua kitab Shahih ini sudah memenuhi kriteria khusus sebagaimana yang ditetapkan oleh kedua penulisnya.

Walaupun kedua kitab hadis Shahih ini berada dalam tingkatan yang tertinggi, namun dalam prakteknya kedua penulisnya berbeda dalam persyaratan, terutama dalam hal persambungan sanad. Seperti yang sudah disinggung di atas, bahwa persyaratan al-Bukhari dalam hal persambungan sanad lebih ketat daripada persyaratan Muslim. AlBukhari mempersyaratkan bertemu, meskipun sekali, antara murid dan guru untuk menunjukkan persambungan sanad, sedang Muslim tidak mempersyaratkan demikian, tetapi cukup dengan hidup dalam kurun waktu yang sama antara murid dan guru (mu'asharah), meskipun tidak saling bertemu.

Sebenarnya Imam al-Bukhari dan Imam Muslim maupun para imam hadis lainnya tidak menyebutkan persyaratan dalam periwayatan hadis secara eksplisit, baik dalam kitab-kitab mereka maupun di luar kitab-kitab mereka. Persyaratan itu baru diketahui setelah dilakukan oleh ulama hadis terhadap kitab-kitab para mukharrij (orang yang mengambil periwayatan). Demikian yang dikatakan oleh Abu al-Fadlal Muhammad bin Thahir al-Maqdisi (alQasthallani, t.t.: 19). Setelah persyaratan itu diketahui, barulah kemudian dirumuskan oleh para ulama sebagai metodologi dalam satu periwayatan hadis.

Hasil penelitian terhadap Jami' al-Shahih karya al-Bukhari menunjukkan bahwa ternyata al-Bukhari dalam sistem periwayatannya selalu memiliki para perawi yang sudah masyhur dalam ke'adilannya, kedlabitannya, serta ketsiqahannya. Untuk menentukan ketersambungan sanad, al-Bukhari mempersyaratkan dua hal, yaitu adalah mu'asharah (sezaman) dan liqa' (ada pertemuan) (alKhathib, 1989: 313). Dua hal inilah yang membedakannya dengan metode yang dimiliki Muslim. Dalam hal ini Muslim cukup mensyaratkan mu'asharah saja, meskipun tidak liqa'. Ketentuan dua hal yang dipegangi al-Bukhari ini (sezaman dan ada pertemuan) berawal dari persepsinya tentang hadis mu'an'an yang menimbulkan perdebatan pemikiran yang terjadi di kalangan ulama hadis yang menyangkut status dan kriteria-kriterianya untuk memenuhi tingkatan muttashil. 
Apa yang terjadi pada al-Bukhari juga terjadi pada Muslim. Dalam kitab Shahihnya, Muslim juga tidak mencantumkan persyaratan periwayatannya secara eksplisit. Ia hanya menuliskan begitu saja riwayat-riwayat yang dianggap shahih berdasarkan hasil ikhtiar dan seleksi secara ketat yang dilakukannya sebelum penulisan.

Pada prinsipnya al-Bukhari dan Muslim menetapkan persyaratan yang sama dalam menentukan derajat keshahihan hadishadisnya, hanya saja dalam hal ketersambungan sanad, al-Bukhari menentukan persyaratan yang lebih ketat daripada Muslim. Bagi Muslim, walaupun hadis itu diriwayatkan secara 'an'anah asal diriwayatkan oleh perawi yang tsiqah, maka status hadis itu sudah menjadi sah atau telah memenuhi syarat qabul al-riwayat dan bisa dijadikan hujjah (al-Khathib, 1989: 317).

Dari ketatnya persyaratan yang diterapkan dalam penyusunan kedua kitab shahih susunan al-Bukhari dan Muslim, maka para ulama sepakata bahwa kedua kitab itu merupakan kitab yang paling shahih (autentik) setelah al-Quran. Terkait dengan hal ini, Ibnu Taymiyah mengatakan: "Tidak ada di bawah kolong langit ini kitab yang lebih shahih dari Shahih al-Bukhari dan Muslim setelah al-Quran" (alKhathib, 1989: 317).

Imam al-Dahlawi juga menyatakan bahwa para ahli hadis sudah sepakat bahwa seluruh hadis muttashil dan marfu' yang termuat dalam kedua kitab shahih (al-Shahihain) itu tidak diragukan keshahihannya. Keduanya mutawatir sampai pada penyusunnya. Dan setiap orang yang menyepelekan urusan dua kitab ini termasuk ahli bid'ah yang mengikuti selain jalan orang-orang yang beriman (al-Khathib, 1989: 317).

\section{Kritik terhadap Kitab Shahih al-Bukhari dan Shahih Muslim}

Kritik hadis merupakan upaya penyeleksian hadis-hadis antara hadis yang shahih dengan hadis yang dla'if dan meneliti para periwayatnya apakah dapat dipercaya dan kuat ingatannya (tsiqah) atau tidak. Kritik hadis sebenarnya sudah dimulai sejak Nabi Muhammad Saw. masih hidup, namun lingkupnya masih sangat terbatas dan motifasinya juga berbeda dengan kritik hadis pada masamasa belakangan.

Untuk menentukan shahih tidaknya sebuah hadis, para ahli hadis pada umumnya mensyaratkan adanya persambungan sanad kepada Nabi Muhammad Saw. dan diriwayatkan oleh periwayatperiwayat yang 'adil (jujur dan takwa) serta dlabit (kuat ingatannya), 
juga tidak ada 'illat (cacat) dan syadz (kejanggalan). Dalam menentukan persambungan sanad kepada Nabi, para ahli hadis mensyaratkan bahwa antara periwayat pertama dengan periwayat kedua, dan begitu juga seterusnya, ada kemungkinan bertemu karena keduanya hidup dalam satu zaman. Jika antara murid dengan guru ada kemungkinan bertemu, para ahli hadis menilai sanad itu bersambung, meskipun tidak pernah bertemu sama sekali. Al-Bukharilah yang paling ketat dalam hal penentuan persambungan sanad ini. Al-Bukhari mengharuskan adanya liqa' (pertemuan) antara murid dengan guru dalam penentuan persambungan sanad. Dan inilah kekhasan persyaratan yang dimiliki oleh al-Bukhari yang tidak dimiliki oleh imam-imam hadis yang lain.

Meskipun dua kitab hadis shahih tersebut memiliki kedudukan yang sangat tinggi dan hampir semua ulama hadis sepakat akan keautentikan hadis-hadis dalam kedua kitab tersebut, ternyata kedua kitab hadis ini tidak luput dari adanya kritik. Kritik terhadap kedua kitab ini tidak hanya dilontarkan oleh para orientalis yang memang sengaja untuk merendahkan kedudukan hadis-hadis Nabi, tetapi juga dari para ulama hadis sendiri. Kritik ini terkadang diarahkan kepada penulisnya, yakni al-Bukhari dan Muslim, dan terkadang juga diarahkan kepada metode yang digunakan oleh keduanya dalam penyusunan kedua kitab tersebut.

Di antara kritik yang diarahkan kepada kedua kitab itu adalah bahwa dalam keduanya termuat hadis-hadis yang mengandung syadz dan 'illat. Ada sekitar 78 hadis dalam Shahih al-Bukhari yang mendapat kritikan, dan dalam kitab Shahih Muslim ada 130 hadis. Para rijal hadis dalam Shahih al-Bukhari yang mendapat sorotan kritik mencapai 80 orang, sedang dalam Shahih Muslim mencapai 160 orang (Badri Khaeruman, 2004: 211).

Terkait dengan rijal hadis yang ada dalam Shahih al-Bukhari, ada seorang periwayat yang bernama Ibnu Abu Laila yang oleh alTirmidzi disoroti secara khusus. Al-Tirmidzi berkata: "Al-Bukhari mengatakan bahwa Ibnu Abi Laila adalah orang terpercaya (shaduq), tetapi saya tidak meriwayatkan satu hadis pun dari dia (Ibnu Abi Laila), karena tidak dapat diketahui mana hadisnya yang benar dan yang keliru. Saya tidak meriwayatkan hadis dari orang yang mempunyai predikat seperti ini” (Muh. Zuhri, 1997: 69). Ini berarti bahwa ulama seperti Ibnu Abi Laila tidak pernah dikelompokkan sebagai rijal hadis shahih. Ada juga yang mengatakan bahwa dari 435 orang rijal hadis al-Bukhari, ada 80 rijal dinilai dla'if. Tetapi tentu saja al-Bukhari, dalam hal ini, lebih mengetahui tentang persepsi 
dirinya terhadap para rijal hadis daripada orang lain. Ada pertimbangan tertentu yang tidak diperhitungkan ulama lain.

Dalam Shahih Muslim juga terdapat rijal hadis yang dinilai lemah oleh pengritiknya. Dari 610 rijal hadis Muslim, ada 160 orang dinilai lemah. Terkait dengan hal ini al-'Asqallani memberikan pembelaan bahwa pemilik rijal hadis lebih mengenalnya daripada pengikutnya ((Muh. Zuhri, 1997: 173).

Ahmad Amin secara khusus memberikan kritik terhadap kedua kitab shahih dalam hal matan. Menurut Ahmad Amin ada matan dalam hadis yang diriwayatkan oleh al-Bukhari dan Muslim yang tidak masuk akal atau tidak benar. Kritikan ini disanggah oleh alHusaini, bahwa terdapat kekurangtelitian Ahmad Amin dalam melakukan kritik terhadap matan hadis yang dikritiknya. Apa yang disoroti Ahmad Amin sebenarnya dapat didudukkan dengan benar jika dilakukan penelitian secara seksama dan lebih teliti lagi (Muh. Zuhri, 1997: 170 dan 174).

Ada juga kritik bahwa materi hadis dalam kedua kitab shahih itu diduga ada yang tidak sempat diteliti. Hal ini muncul ketika terlihat satu atau dua hadis yang diriwayatkan al-Bukhari yang materinya bertentangan dengan riwayat yang lebih shahih atau mutawatir seperti al-Quran. Ada juga yang mengritik bahwa seperempat isi kitab Shahih al-Bukhari merupakan hadis mu'allaq. Namun kritik ini dibantah oleh al-Suyuthi dan telah pula didudukkan persoalannya oleh 'Ajjaj alKhathib (1989: 313).

Ada sebagian pengritik yang menyatakan bahwa dalam kedua kitab shahih itu juga terdapat hadis-hadis ma'lul (cacat). Hal ini kemudian dibantah oleh Ibnu Hajar al-'Asqallani yang menyatakan bahwa al-Bukhari dan Muslim lebih tahu tentang hadis-hadis ma'lul ketimbang para pengritiknya. Jika ada orang yang menyatakan bahwa dalam Shahih al-Bukhari terdapat hadis-hadis ma'lul, kritik ini yang justeru dipertanyakan (Badri Khaeruman, 2004: 215).

Kritik dan sorotan yang diarahkan kepada dua kitab alShahihain tersebut hingga kini masih muncul, terutama dalam hal matan atau isi hadisnya. Terkait dengan perkembangan IPTEKS sekarang ini dan merebaknya era persamaan dan keadilan, tidak menutup kemungkinan matan hadis yang secara tekstual menunjukkan penguatan kepada kaum atau golongan tertentu akan mendapat sorotan dari para pengritik yang tidak menghendaki legitimasi ketidakadilan. Dalam masalah gender, misalnya, kaum feminis masih banyak yang menyoroti beberapa hadis yang dinilai misoginis (merendahkan posisi kaum perempuan), termasuk hadis-hadis yang terdapat dalam kedua 
kitab shahih tersebut. Terkait dengan hal ini ada yang secara tegas mengatakan bahwa hadis-hadis yang menunjukkan ketidakadilan ini termasuk hadis yang lemah (tidak shahih), namun ada yang tetap mempertahankan keshahihannya, dan upaya yang dilakukan adalah dengan memahami dan menafsirkannya secara kontekstual sehingga tidak bertentangan dengan semangat al-Quran yang menjunjung tinggi persamaan dan keadilan.

\section{Penutup}

Demikianlah kajian sederhana tentang kritik hadis terhadap kitab Shahih al-Bukhari dan Shahih Muslim. Tentu saja, kajian ini masih jauh dari sempurna, sebab apa yang penulis lakukan hanya mereformulasi apa yang sudah dilakukan oleh para pengkaji yang sudah ada. Keterbatasanlah yang menghalangi adanya kajian langsung terhadap objeknya, yakni kitab al-Shahihain.

Akhirnya penulis berharap semoga tulisan yang sangat sederhana ini bermanfaat bagi para pembaca umumnya dan khususnya bagi penulis, terutama untuk membekali pemahaman para pemakai hadis yang terkadang menerima dengan bulat-bulat semua hadis yang diriwayatkan oleh Imam al-Bukhari dan Imam Muslim.

\section{Daftar Pustaka}

Abu Syahbah, Muhammad. (1969). Fi Rihab al-Sunnah al-Kutub alShahhah al-Sittah. Kairo: al-Buhuts al-Islamiyyah.

Ali Mustafa Yaqub. (1996). Imam Bukhari \& Metodologi Kritik dalam Ilmu Hadis. Jakarta: Pustaka Firdaus, Cet. III.

Al-Khathib, Muhammad 'Ajjaj. (1989). 'Ulum al-Hadis 'Ulumuhu wa Mushthalahuhu. Beirut: Dar al-Fikr.

(2004). Kritik Hadis. Jakarta: Pustaka Firdaus. Cet. IV.

Al-Nawawi. (1402). Syarh Muslim. Beirut: Dar al-Fikr.

Al-Qasthallani, Ahmad. (t.t.). Irsyad al-Syari li Syarhi Shahih alBukhari. T.tp.: t.p. 
Badri Khaeruman. (2004). Otentisitas Hadis: Studi Kritis atas Kajian Hadis Kontemporer. Bandung: Remaja Rosdakarya.

Muhammad Musthafa 'Azami. (1992). Metodologi Kritik Hadis. Alih bahasa oleh A. Yamin. Bandung: Pustaka Hidayah.

Muh. Zuhri. (1997). Hadis Nabi: Telaah Kritis dan Metodologis. Yogyakarta: Tiara Wacana. Cet. I.

\section{Biodata Penulis}

Marzuki, M.Ag., dilahirkan di Banyuwangi, 21 April 1966. Menyelesaikan studi S-1 di Fakultas Tarbiyah IAIN Sunan Kalijaga Yogyakarta tahun 1990. Kemudian menyelesaikan studi S-2 bidang Pengkajian Islam di Pascasarjana IAIN Syarif Hidayatullah Jakarta tahun 1997. Sejak tahun 1992 menjadi dosen tetap Universitas Negeri Yogyakarta dalam mata kuliah Pendidikan Agama Islam. Sejak tahun 1996 juga mengampu mata kuliah Hukum Islam di Jurusan PPKn FIS UNY yang juga menjadi kantornya hingga sekarang ini. Tulisantulisannya banyak terkait dengan permasalahan hukum Islam, pendidikan Islam, dan gender. 